\title{
Pemanfaatan Alat Pengering Pada Industri Rumah Tangga Keripik Nenas “Nafiz” Desa Rimbo Panjang, Kampar
}

Rafil Arizona ${ }^{1}$, Jhonni Rahman ${ }^{1 *}$, Kurnia Hastuti ${ }^{1}$, Eddy Elfiano $^{1}$, Yoga Fernando ${ }^{1}$, Shandy Kurniadi ${ }^{1}$ ${ }^{1}$ Program Studi Teknik Mesin, Fakultas Teknik, Universitas Islam Riau, Jln. Kaharuddin Nasution Km. 113 Marpoyan, Pekanbaru, Riau, Indonesia - 28284

*Penulis koresponden: jhonni rahman@eng.uir.ac.id

\begin{tabular}{l}
\hline Info Artikel \\
\hline Riwayat : \\
Dikirim 1 Desember 2021 \\
Direvisi 30 Desember 2021 \\
Diterima 31 Desember 2021
\end{tabular}

\section{Kata Kunci :}

Keripik Nenas

Ekonomi

Teknologi Sederhana

Pengering

\begin{abstract}
Abstrak
Sebagai daerah penghasil nenas yang cukup besar, masyarakat Riau khususnya desa Rimbo Panjang, Kabupaten Kampar memanfaatkan nanas dengan mengolahnya menjadi beberapa produk yang bernilai ekonomi. Salah satu diantaranya adalah keripik nenas. Kegiatan PkM ini dilakukan untuk memperkenalkan kepada masyarakat tentang teknologi sederhana yang dapat digunakan dalam membantu mempercepat proses pengeringan buah nenas yaitu dengan memanfaatkan alat pengering. Kegiatan $\mathrm{PkM}$ ini diawali dengan pembuatan alat pengering nenas yang kemudian digunakan saat sosialisasi untuk mempermudah masyarakat dalam memahami materi penyampaian tentang teknologi pengeringan sederhana yang disampaikan oleh para nara sumber. Setelah itu, kegiatan dilanjutkan dengan mengeringkan buah nenas menggunakan alat pengering yang telah dibuat. Kegiatan PkM ini dinilai berhasil karena karena tujuan yang diharapkan dari pelaksanaan kegiatan berjalan dengan baik dan efektif. Hal ini dapat dilihat dari besarnya antusias peserta ketika kegiatan berlangsung. Selain itu, masyarakat menjadi faham bahwa penggunaan alat pengering tidak hanya mempercepat proses pengeringan buah nenas tetapi juga menjaga agar buah nenas tetap bersih dan higienis.
\end{abstract}

\section{PENDAHULUAN}

\section{Latar Belakang}

Nanas merupakan tanaman buah semak yang memiliki nama ilmiah Ananas comosus. Dalam bahasa Inggris nenas disebut dengan nama Pineapple, sehingga orang-orang Spanyol menyebutnya dengan nama Pina. Menurut Rukmana (2007), Nanas atau "Pineapple" bukan tanaman asli Indonesia. Penyebaran nanas di Indonesia pada mulanya hanya digunakan sebagai tanaman pengisi lahan pekarangan. Lambat laun meluas dan dikebunkan di seluruh wilayah nusantara.

Buah nenas (Ananas comosus) merupakan salah satu jenis buah di daerah tropis dan mempunyai penyebaran yang merata, serta memiliki produktivitas yang tinggi dan nilai ekspor yang mampu bersaing di pasar internasional (Landi, 2017). Nenas dibawa ke Indonesia pada abad ke 15 yaitu sekitar tahun 1599 (Rukmana, 2007). Pada awal mulanya tanaman ini hanya difungsikan sebagai tanaman hias di perkarangan rumah masyarakat saja. Namun setelah mengalami pengembangan lebih lanjut akhirnya nenas mulai ditanam di lahan kering dan dikebunkan. Daerah tropis dan subtropis merupakan iklim yang sangat baik bagi nenas untuk tumbuh dan berkembang.

Sebagai warga Indonesia tentu kita sangat familiar dengan buah nenas, buah ini biasanya dikonsumsi pada siang hari karena kandungan airnya yang banyak dan sangat menyegarkan jika dikonsumsi. Selain dikonsumsi harian, buah nenas juga memiliki prospek usaha yang sangat menjanjikan dengan potensi bisnis yang besar jika dikelola dengan baik dan teratur. Pada beberapa usaha kecil menengah (UKM) nenas dijadikan sebagai salah satu komoditi bahan baku utama dari sebuah produk seperti keripik, selai, sirup, minuman kaleng, minuman segar dan lain-lain. Provinsi 
Riau merupakan salah satu provinsi penghasil nenas terbesar di Indonesia. Hal itu dinyatakan dalam data statistik yang diperoleh dari Pusat data informasi Kementerian Pertanian tahun 2015. Selain potensinya luar biasa, Nenas juga memiliki banyak peminat dari manca negara terutama di negaranegara tetangga seperti Malaysia, Singapura dan Filipina. Sehingga nenas memiliki potensi untuk di ekspor ke berbagai daerah hingga ke mancanegara. Data statistik daerah penghasil nanas di Indonesia ditunjukan pada tabel 1.

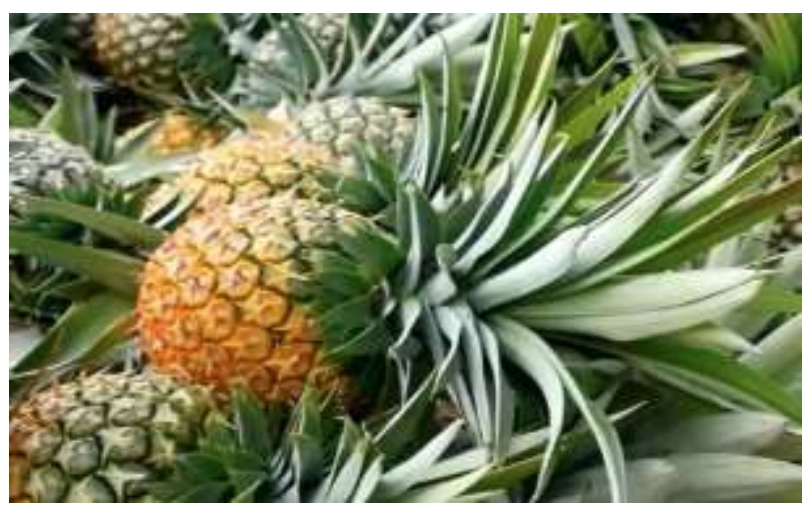

Gambar 1. Buah nenas (Riauonline, 2020).

Tabel 1. Data statistik daerah penghasil nanas di Indonesia (Direktorat Jendral Hortikultura, 2015).

\begin{tabular}{|c|l|c|c|c|c|c|c|c|}
\hline \multirow{2}{*}{ No } & \multirow{2}{*}{ Provinsi } & \multicolumn{6}{|c|}{ Produksi (Ton) } & Kontribusi \\
\cline { 3 - 9 } & & 2010 & 2011 & 2012 & 2013 & 2014 & Rata-rata & $(\%)$ \\
\hline 1 & Lampung & 469.034 & 505.337 & 585.608 & 722.621 & 560.026 & 568.525 & 33,65 \\
\hline 2 & Jawa Barat & 385.640 & 315.016 & 174.451 & 95.015 & 149.815 & 223.987 & 13,26 \\
\hline 3 & $\begin{array}{l}\text { Sumatra } \\
\text { Utara }\end{array}$ & 102.438 & 183.213 & 262.089 & 228.136 & 237.581 & 202.691 & 12 \\
\hline 4 & Jawa Timur & 72.404 & 40.045 & 196.581 & 197.165 & 186.949 & 138.629 & 8,21 \\
\hline 5 & Jambi & 31.165 & 67.530 & 144.896 & 156.369 & 218.861 & 123.764 & 7,33 \\
\hline 6 & $\begin{array}{l}\text { Jawa } \\
\text { Tengah }\end{array}$ & 58.163 & 92.953 & 69.058 & 113.093 & 107.438 & 95.068 & 5,68 \\
\hline 7 & Riau & 19.838 & 109.374 & 92.444 & 96.173 & 107.438 & 85.053 & 5,03 \\
\hline 8 & $\begin{array}{l}\text { Kalimantan } \\
\text { Barat }\end{array}$ & 56.190 & 73.815 & 108.704 & 90.570 & 86.530 & 83.162 & 4,92 \\
\hline 9 & $\begin{array}{l}\text { Sumatera } \\
\text { Selatan }\end{array}$ & 114.305 & 76.423 & 47.342 & 57.887 & 57.990 & 70.789 & 4,19 \\
\hline 10 & $\begin{array}{l}\text { Kalimantan } \\
\text { Timur }\end{array}$ & 14.434 & 13.292 & 21.074 & 26.731 & 25.637 & 20.441 & 1,21 \\
\hline & Lainnya & 82,434 & 62.991 & 79.648 & 99.044 & 62.584 & 77.340 & 4,58 \\
\hline & Indonesia & 1.408 .445 & 1.540 .626 & 1.781 .894 & 1.882 .802 & 1.835 .483 & 1.689 .450 & 100 \\
\hline
\end{tabular}

Terlihat dari tabel 1 propinsi Riau merupakan sebagai salah satu provinsi penghasil nenas terbesar ketujuh di Indonesia. Sehingga tidak jarang sering ditemukan petani nenas yang menjual nenas segar maupun produk nenas olahan yang beraneka ragam (Afifah dkk, 2019; Suprapti, 2001). Salah satu komuditi hasil olahan nenas yang cukup dikenal di wilayah propinsi Riau dan menjadi makanan khas Riau adalah keripik nenas (Kusumawaty, 2018). Namun realitanya masih banyak petani nanas di propinsi Riau yang belum mampu mengelola nanas secara maksimal. Banyak kendala yang dialami oleh petani nenas maupun industri rumah tangga dalam mengelola dan memproduksi olahan nenas. Secara umum industri kecil masih menggunakan cara tradisional dalam memproduksi olahan nenas. Salah satu contoh adalah mereka mengeringkan buah nenas dengan cara memanaskan langsung dari matahari diruang terbuka. Proses seperti ini memerlukan waktu yang sangat lama dan hanya dapat dilakukan menyesuaikan dengan kondisi alam. Ketika matahari panas mereka dapat mengeringkan dengan baik, meskipun membutuhkan waktu yang lama. Sedangkan ketika hari hujan 

mereka tidak dapat berbuat apa-apa. Kerugian lainnya menggunakan tradisional adalah buah nenas yang dijemur di bawah terik matahari cendrung tidak bersih karena pengaruh lingkungan sekitar. Oleh karena itu tidak sedikit para pengusaha olahan buah nenas di desa Rimbo Panjang menggunakan jasa dari pihak kedua dalam mengelola buah nenas.

Dalam proses produksi keripik nenas masyarakat Rimbo Panjang melakukannya dalam beberapa tahap. Pertama, tahap pengumpulan buah nenas. Proses pengumpulan nenas umumnya dilakukan atau dikumpulkan dari kebun mereka sendiri atau dari petani nenas lainnya. Tahapan selanjutnya adalah proses pembersihan. Pembersihan dilakukan dengan mengupas kulit dan memotong sesuai dengan ukuran keripik yang akan diproduksi. Tahapan yang ketiga adalah tahap pengeringan. Pada tahapan ini sebelumnya pengusaha keripik nenas melakukannya dengan menjemur langsung di bawah matahari. Namun hal ini sangat menyusahkan dan memiliki beberapa kelemahan yang dapat menghambat produksi keripik nenas. Tetapi, sekarang ini proses pengeringan dilakukan dengan menggunakan alat pengering yang disewa dari pihak lain dengan harga yang cukup besar. Dan yang terakhir adalah proses penggorengan sebelum dikemas dan dijual kepada pelanggan. Proses penggorengan merupakan salah satu tahapan penting yang menentukan kualitas produk keripik nenas (Tumbel, 2017). Salah satu industri rumah tangga yang menggunakan tahapan seperti ini adalah industry rumah tangga yang menamakan usaha mereka dengan nama "NAFIZ".

Dari tahapan-tahapan diatas yang menjadi fokus pembahasan dalam kegiatan Pengabdian kepada Masyarakat (PkM) yang kami lakukan adalah proses pengeringan. Seperti yang telah dijelaskan bahwa pengeringan yang dilakukan oleh Industri Rumah Tangga NAFIZ adalah dengan menyewa alat dengan harga yang yang sebenarnya dapat digunakan untuk memenuhi kebutuhan lain. Ditambah lagi harga sewa yang cendrung flaktuatif membuat penghasilan cendrung tidak stabil. Oleh karena itu pengusaha keripik nenas di desa Rimbo Panjang membutuhkan sebuah alat yang dapat membantu mereka dalam proses pengeringan buat nenas dengan biaya yang relative lebih murah.

\section{Teknologi Pengering}

Pengeringan merupakan suatu metode yang dilakukan untuk mengeluarkan atau menghilangkan sebagian air yang terkandung dalam sebuah bahan/benda dengan cara menguapkan air tersebut dengan menggunakan energi panas. Asgar \& Musaddad (1998) menjelaskan faktor-faktor eksternal yang mempengaruhi produk yang dihasilkan dari proses pengeringan, salah satunya adalah suhu yang telalu tinggi. Selain itu, kecepatan angin atau udara yang mengalir pada sistem pengering. Udara yang tidak mengalir pada suatu sistem akan menyebabkan udara menjadi jenuh yang membuat laju pengeringan menjadi lambat. Proses pengeringan dapat dikategorikan menjadi dua cara, yaitu pengeringan alami dan pengeringan buatan. Pengeringan alami adalah pengeringan yang dilakukan dengan mengharapkan sinar matahari secara langsung maupun tidak langsung. Sedangkan pengeringan buatan adalah sistem pengeringan yang dilakukan dengan menggunakan alat bantu dalam proses pengeringan.

Kemampuan pengeringan buatan (artificial drying) yang menggunakan alat pengering ditentukan oleh beberapa faktor penting seperti tinggi rendahnya suhu, kelembaban udara, kecepatan aliran udara dalam sistem pengering dan waktu yang dibutuhkan dalam proses pengeringan. Mengabaikan salah satu faktor-faktor tersebut dapat mengakibatkan kualitas pengeringan bahan menjadi tidak baik (Yulianto dkk, 2018). Salah satu bentuk kegagalan yang mungkin terjadi adalah case hardening. Yaitu suatu kondisi dimana bahan tidak kering secara merata, bagian tertentu kering sedangkan bagian lain masih basah. Sistem pengeringan buatan ini berdasarkan media pengeringan dikelompokkan menjadi dua yaitu pengeringan adiabatik dan pengeringan isothermik. Sistem pengeringan adiabatik yaitu sebuah sistem pengeringan yang memanfaatkan aliran udara panas yang disalurkan. Biasanya sistem pengeringan ini digunakan mengeringkan sayur dan buah-buahan dalam laboratorium (Lastrianto dkk, 2017). Sedangkan pengeringan isothermik adalah sistem pengeringan yang memanfaatkan kontak langsung antara media pengering dengan bahan yang dikeringkan.

Proses pengeringan pada prinsipnya mengurangi kandungan air yang ada dalam suatu benda (dalam kasus ini adalah buah nenas) sampai batas tertentu yang diinginkan. Faktor-faktor yang mempengaruhi proses pengeringan secara garis besar digolongkan menjadi dua golongan. Pertama adalah faktor yang berhubungan dengan udara pengering. Cepat lambatnya proses pengeringan oleh udara ditentukan berdasarkan suhu, kecepatan udara, kelembaban udara, dan arah aliran udara. Semakin tinggi udara yang mengalir semakin cepat proses pengeringan. Begitu juga halnya dengan kecepatan aliran udara, semakin cepat udara dialirkan dalam sistem pengering semakin cepat proses pengeringan dan seterusnya. Faktor yang kedua yang menentukan kecepatan proses pengeringan 
adalah faktor yang berhubungan dengan bahan itu sendiri seperti ukuran bahan dan kandungan air yang terdapat dalam bahan yang akan dikeringkan.

\section{METODE PELAKSANAAN}

Pelaksanaan kegiatan Pengabdian kepada Masyarakat (PkM) dilaksanakan di sebuah desa penghasil buah nenas yang cukup besar yaitu desa Rimbo Panjang, kecamatan Tambang, kabupaten Kampar, propinsi Riau pada mulai dari bulan November 2020 sampai September 2021. Kegiatan PkM ini dilaksanakan melalui empat tahapan, yaitu,

1. Tahapan pertama, survei lapangan untuk mengidentifikasi permasalahan yang terjadi di desa Rimbo Panjang, serta kebutuhan teknologi dan alat dalam mengurangi permasalahan yang mereka hadapi.

2. Tahapan kedua, proses desain dan pembuatan alat pengering yang sesuai dengan kebutuhan pengeringan buah nenas.

3. Tahapan ketiga, sosialisasi teknologi sederhana yang dapat diimplementasikan serta tata cara penggunaan alat pengering yang sudah dibuat.

4. Tahapan keempat, evaluasi pelaksanaan PkM dan penyusunan laporan.

\section{HASIL DAN PEMBAHASAN}

Kegiatan Pengabdian kepada Masyarakat yang dilakukan di desa Rimbo Panjang sebagai daerah penghasil pertanian nenas dan juga sebagai daerah pengolah nenas menjadi produk yang bernilai ekonomi yaitu keripik nenas diawali dengan melakukan survei lapangan ke desa Rimbo Panjang untuk mendapatkan informasi-informasi yang dibutuhkan untuk merencanakan model teknologi yang dibutuhkan masyarakat setempat. Survei lapangan dilakukan dengan meninjau daerah penghasil nenas dan melakukan wawancara untuk mengidentifikasi masalah yang sedang dihadapi oleh masyarakat setempat dan juga untuk merumuskan solusi apa yang tepat untuk menyelesaikan atau mengurangi masalah yang dihadapi oleh masyarakat.

Tahapan kedua adalah merencanakan alat yang dapat digunakan sebagai solusi dalam mengurangi bebab atau permasalahan yang dihadapi oleh masyarakat setempat. Berdasarkan survei lapangan yang telah dilakukan didapatkan informasi bahwa saat ini alat yang mereka butuhkan adalah alat pengering buah nenas. Sekarang ini masyarakat Rimbo Panjang khususnya pengusaha keripik nenas menggunakan alat pengering yang mereka sewa dari pihak lain. Hal ini mereka lakukna karena ketidak mampuan mereka untuk membeli alat tersebut. Sehingga sistem sewa menjadi satu satunya solusi bagi mereka untuk meningkatkan kuantitas produksi yang dibutuhkan. Keterangan inilah yang menjadi dasar dalam merencanakan alat yang dibuat untuk masyarakat Rimbo Panjang. Gambar 2 menunjukkan kondisi alat pengering yang sedang difabrikasi. Proses pembuatan alat dilakukan selama sekitar dua bulan (pertengahan Januari sampai awal Maret 2021) mulai dari membuat desain alat sesuai dengan kebutuhan sampai proses fabrikasi.

Setelah pembuatan alat pengering selesai dibuat, kemudian dilakukan perencanaan waktu yang tepat untuk memberikan penyuluhan kepada masyarakat serta mensosialisasikan teknologiteknologi sederhana yang dapat dibuat dengan mudah namun berguna dalam menjawab permasalahan yang mereka hadapi. Kegiatan penyuluhan/sosialisai dilakukan langsung di desa Rimbo Panjang pada tanggal 14 Maret 2021, tepatnya di sebuah industri rumah tangga keripik nenas milik ibu Nur Hasanah Gultom. Kegiatan sosialisasi diawali dengan memperkenalkan tim dari Prodi Teknik Mesin yang berkunjung langsung ke desa Rimbo Panjang. Dilanjutkan dengan penyampaian materi mengenai teknologi sederhana dan alat pengering oleh naras umber dan diakhiri dengan penjelasan tentang proses penggunaan alat pengring yang telah dibuat. Kegiatan sosialisasi berjalan dengan baik dan lancar yang disertai dengan diskusi timbal balik antara kedua belah pihak. Gambar 3 dan 4 merupakan foto yang diambil ketika berdiskusi tentang alat pengering nenas dan ketika menjelaskan proses penggunaan alat. Sedangkan gambar 5 adalah foto bersama yang diambil sebelum berpisah dengan pemilik usaha keripik nenas NAFIZ. 


\section{Buletin Pembangunan Berkelanjutan}

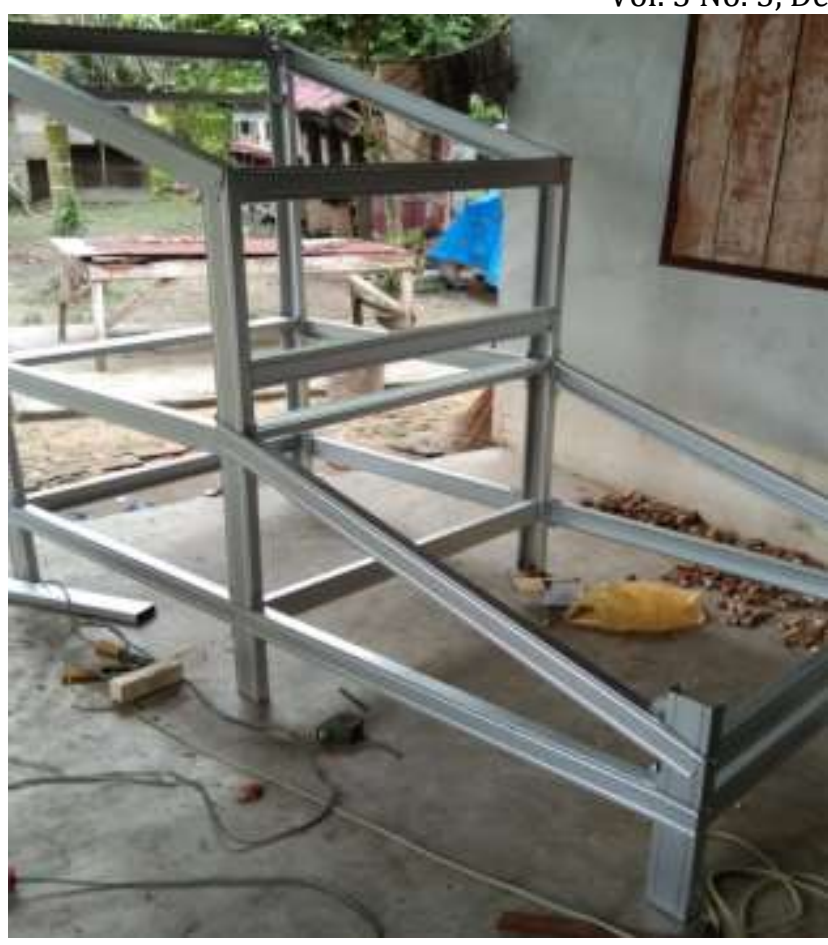

Gambar 2. Proses pembuatan alat pengering nenas

Tahapan terakhir dari serangkaian kegiatan PkM adalah evaluasi kegiatan yang disusun dalam laporan kegiatan sebagai bahan pembelajaran untuk kegiatan PkM selanjutnya serta rencana kedepan dalam membangun masyarakat desa Rimbo Panjang yang lebih baik.

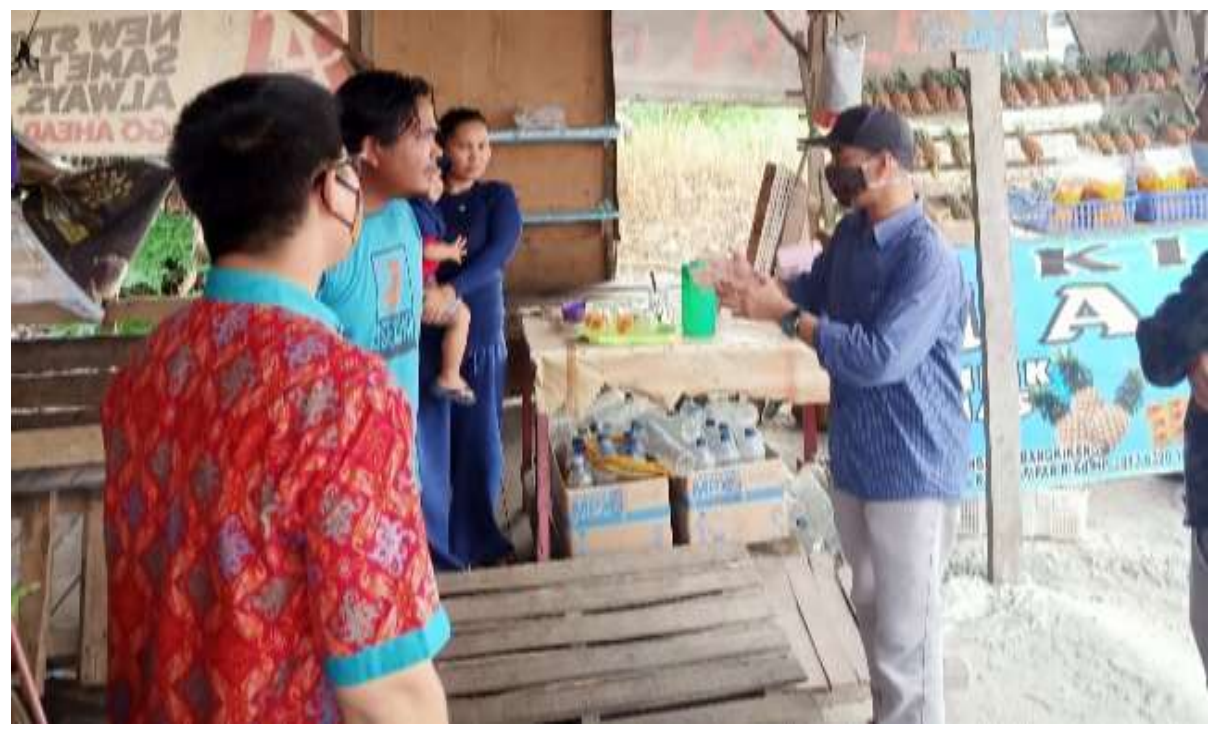

Gambar 3. Diskusi tentang alat pengering nenas 
Buletin Pembangunan Berkelanjutan

Vol. 5 No. 3, Desember 2021 hal. 21-27

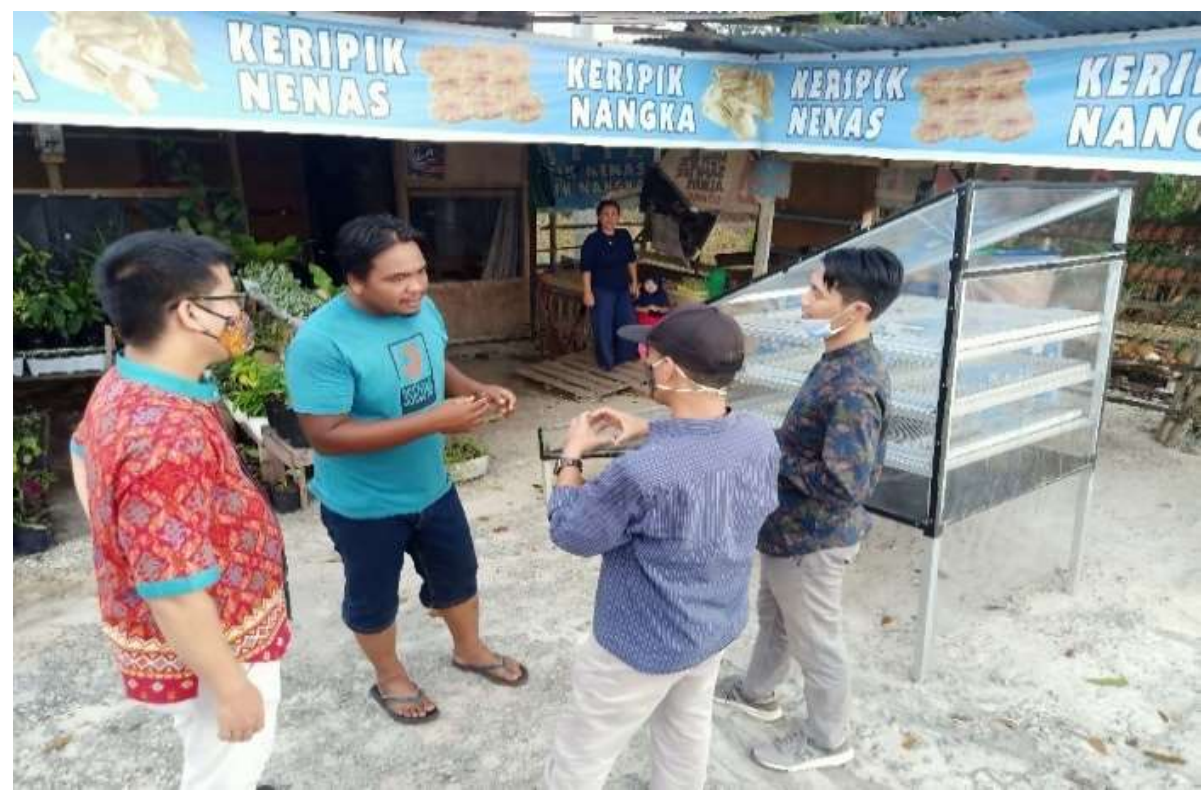

Gambar 4. Menjelaskan proses penggunaan alat pengering nenas

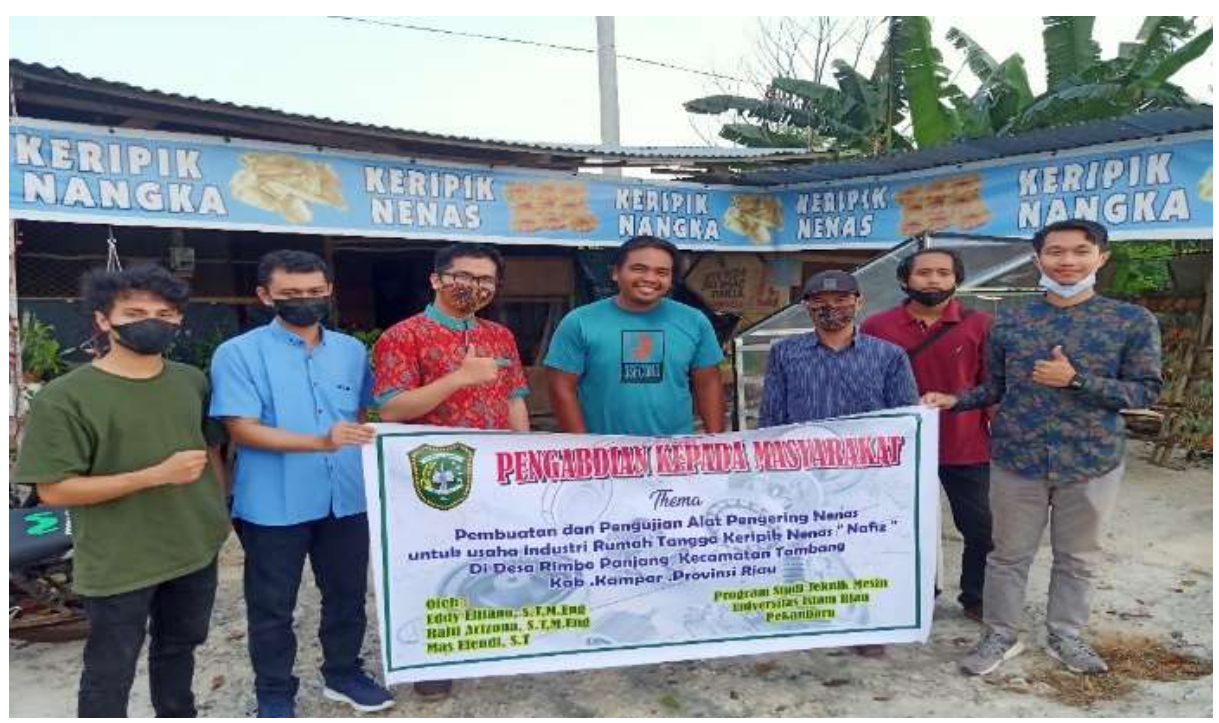

Gambar 5. Foto Bersama dengan pemilik usaha keripik nenas NAFIZ

\section{KESIMPULAN}

Kegiatan Pengabdian kepada Masyarakat (PkM) yang dilakukan di desa Rimbo Panjang kabupaten Kampar terlaksanakan dengan baik dan lancar, serta memberi dampak yang positif bagi masyarakat sekitar yang dapat disimpulkan dalam beberapa poin sebagai berikut,

1. Proses transfer ilmu tersalurkan dengan baik dan lancar.

2. Menyadarkan masyarakat akan pentingnya ilmu pengetahuan dan teknologi dalam menyelesaikan masalah yang dihapadapi.

3. Masyarakat mengerti dan faham cara menggunakan alat pengering untuk buah nenas. 
Kami ucapkan terimakasih kepada seluruh pihak yang terlibat dalam kegiatan PkM ini, terutama DPPM Universitas Islam Riau yang telah memberikan support dalam bentuk finansial dan Industri Rumah Tangga (IRT) keripik nenas NAFIZ yang telah menerima kami di desa Rimbo Pandang serta seluruh warga desa Rimbo Panjang.

\section{DAFTAR PUSTAKA}

Afifah, D. N., Fuadi, A., Nugraheni, N., Arifan, F., \& Pratiwi, S. N. (2019). PRODUK PANGAN DAN NONPANGAN OLAHAN NANAS MADU.

Asgar, A., \& Musaddad, D. (2008). Pengaruh media, suhu, dan lama blansing sebelum pengeringan terhadap mutu lobak kering. Jurnal Hortikultura, 18(1).

Kusumawaty, Y., 2018. Strategi pemasaran produk makanan ringan khas Riau (keripik nenas dan rengginang ubi kayu). Jurnal Agribisnis, 20(2), pp.124-138.

Lastriyanto, A., Soeparman, S., Soenoko, R., \& HS, S. (2017). Identifikasi Laju Penguapan Air Pada Penggorengan Vakum Buah Nanas. 2002, 593-602.

Landi, H. K. (2017). Analisis Daya Saing Ekspor Buah Nenas Kalengan Indonesia di Pasar Internasional (Doctoral dissertation, Universitas Jenderal Soedirman).

Riauonline. (2020). https://www.riauonline.co.id/riau/kota-pekanbaru/read/2020/12/16/terkenalmanis-buah-nenas-jadi-produksi-tertinggi-riau-2019

Statistik, B. P. (2015). Direktorat Jenderal Hortikultura. 2015. Produktivitas sayuran di Indonesia, 2016.

Suprapti, M. L. (2001). Membuat aneka olahan nanas.

Tumbel, N. (2017). Pengaruh Suhu Dan Waktu Penggorengan Terhadap Mutu Keripik Nanas Menggunakan Penggoreng Vakum. Jurnal Penelitian Teknologi Industri, 9(1), 9.

Yulianto, E., Yohana, E., Sutrisno, S., Utami H, S., Ariwibowo, D., Fardzanela S, F. S., \& Sitawati, R. (2018). Peningkatan Produktivitas Industri Manisan Nanas Melalui Pengembangan Pengering Multi Rak. Metana, 14(2), 43.

Rukmana. (2007). Nenas Budidaya dan Pasca Panen. Yogyakarta: Kasinius. 